\title{
A educação sofística (constantemente referida por Platão)
}

Gabrielle Cavalcante

Universidade Federal do Ceará

\section{Resumo}

É lugar-comum entre os helenistas dizer que durante o século $V$ a.C desenvolveu-se em Atenas um movimento, chamado sofística, que deu origem à educação propriamente dita. Pode-se dizer que os chamados sofistas são considerados os primeiros "docentes profissionais", que cobravam pelos seus ensinamentos. O presente trabalho pretende apresentar uma caracterização dos sofistas como educadores. Entretanto, tal caracterização não pode ser encontrada diretamente nos fragmentos que restaram dos próprios sofistas. Para tanto, recorreremos ao testemunho de Platão nos seus diálogos Protágoras e Górgias, as fontes mais diretas acerca dos objetos, métodos e destinatários do ensino desses dois sofistas.

Palavras-chave: Sofística; Educação; Platão.

\section{Resumen}

Es lugar común entre los helenistas decir que durante el siglo V a.C. se ha desarollado en Atenas un movimiento, llamado sofística, que dio origen a la educación propiamente dicha. Se puede decir que los llamados sofistas son considerados los primeros "maestros profesionales", que cobraban por sus enseñanzas. El presente trabajo pretende presentar una caracterización de los sofistas como educadores. Sin embargo, tal caracterización no puede ser encontrada directamente en los fragmentos que quedaran de los propios sofistas. Para esto, vamos a recurrir al testimonio de Platón en sus diálogos Protágoras e Gorgias, las fuentes más directas acerca de los objetos, métodos y destinatarios de la enseñanza de estos dos sofistas.

Palabras clave: Sofística; Educación; Platón.

Filosofia e Educação [RFE] - Volume 9, Número 1 - Campinas, SP

Fevereiro-Maio de 2017 - ISSN 1984-9605 - p. 111- 
o estudarmos mais a fundo o que nos restou dos fragmentos dos próprios sofistas, percebemos que praticamente nada sobrou em relação a suas 1 atividades como professores. Mais que isso, percebemos também que a maior parte das informações que possuímos sobre essas atividades vêm dos diálogos platônicos - aqueles mesmos que, muitas vezes, os trataram de modo bastante hostil ${ }^{2}$. Não quero dizer com isso que não podemos falar sobre a ação dos sofistas como educadores ou que devamos desconsiderar o "testemunho" platônico simplesmente por não termos uma comprovação em textos dos próprios sofistas. Podemos sim falar dos sofistas como educadores e levar em consideração o que dizem os diálogos de Platão, sempre tendo em vista, contudo, que se trata do que Platão colocou na boca dessas personagens ao longo de seus diálogos e não o que eles próprios escreveram.

Assim sendo, nosso trabalho tentará fazer uma caracterização dos sofistas enquanto educadores a partir do que dizem os diálogos platônicos - principalmente, o Protágoras e o Górgias, mas não sem antes tentar responder brevemente a algumas perguntas fundamentais: O que é o sofista? Quem são esses homens que são comumente conhecidos na nossa história da filosofia por este termo? De onde provêm as informações que temos sobre suas teorias? Do que se ocupavam? Para tentar responder a essas questões - ainda que de modo bastante parcial - divido este trabalho em três momentos distintos: o primeiro tentará fazer uma breve exposição do que se diz ser um sofista, do contexto em que viveram e quais são seus objetos de ensino e métodos, enquanto o segundo exporá rapidamente alguns sofistas de modo individual; e apenas

1 Atento, antes de mais nada, para a difícil tarefa de expor um tema tão complexo em tão poucas páginas. A sofística foi tema de diversos estudos e livros de numerosas páginas, e ainda hoje é um assunto bastante polêmico entre os comentadores. De modo que me vi condicionada a escolher entre uma abordagem mais aprofundada e especializada de determinado pensador ou uma mais generalista que tenta dar conta das características consideradas "mestras" de alguns desses pensadores. Opto então pela segunda das duas alternativas, apoiando-me amplamente nos textos que estão listados nas referências bibliográficas. Com este tipo de abordagem será, obviamente, impossível não recorrer a lugares-comuns e "gerais" amplamente conhecidos pelos estudiosos de filosofia antiga, sendo este artigo destinado, antes de tudo, a estudantes de educação que não tenham um conhecimento mais aprofundado da sofística, mas que se interessam por conhecê-la um pouco mais e que serão capazes de aprofundar a pesquisa, caso queiram, a partir dos livros indicados em nossas referências bibliográficas. Deste modo, abstenho-me também das longas citações ou referências que acabam tornando um texto de filosofia antiga muito "truncado" para aqueles que não estão familiarizados com o modo de se fazer pesquisa em qualquer autor antigo. Aviso, por fim, que minha pesquisa e tudo que estará escrito nesse texto não são ideias originais, mas retiradas de uma vasta tradição historiográfica que venho pesquisando desde meados de 2009, sendo, portanto, apenas mais uma pequeníssima história a respeito da sofística.

2 As referências aos sofistas nos diálogos platônicos são inúmeras e em toda parte, chegando mesmo a ter obras dedicadas a alguns em particular. Cito os diálogos que mais se detêm sobre eles: Eutidemo, Sofista, Teeteto, Protágoras, Górgias, Mênon, Hipias Maior e Hípias Menor. 
no terceiro momento, entro realmente na caracterização feita por Platão nos já citados diálogos.

\section{O que é um sofista?}

Antes de mais nada, não pretendo aqui determinar o que se entende por sofista ou tentar percorrer novamente toda a história do conceito sofista, isso demandaria muito tempo, é um assunto bastante conhecido e pode ser encontrado em muitos lugares. ${ }^{3}$ Porém, pretendo alertar para os diversos problemas que se colocam ao evocarmos o termo "sofista". Basicamente temos de lidar com dois grandes empecilhos antes de qualquer tentativa de "interpretação" desses pensadores, a saber, a carência de seus escritos - o que sobreviveu até nossos dias foram pouquíssimos fragmentos transmitidos de forma indireta $^{4}$-, e a má reputação colocada sobre eles desde os tempos antigos. Assim sendo, falar da sofística, abordando o aspecto que seja, é falar sempre através de uma imagem produzida por muitas pessoas e alguns escassos fragmentos diretos que são fonte tanto do nosso conhecimento como desconhecimento da sofística.

Mas, como dito desde o início, o que me interessa aqui é descrevê-los a partir da atividade de educadores: os sofistas aparecem na cena da polis grega, por volta de 450 a 400 a.C., como os primeiros educadores profissionais, especialistas no ensino da linguagem e de cultura geral. Eram oriundos de diversas partes do mundo grego, e passavam - em sua maioria - a maior parte da vida viajando exatamente por conta da sua atividade profissional.

Não por acaso o grande centro de suas atividades parece ter sido a Atenas democrática. Em um regime democrático o acesso ao poder deixa de ser legitimado pela pertença a uma determinada estirpe que portava autoridade e influência - como era na época da Grécia aristocrata - e passa a ser obtido através do consenso entre outros cidadãos. Assim, torna-se necessário, antes de qualquer coisa, dominar a arte de falar nas assembléias e de gerar a persuasão. Arte essa que a maioria dos sofistas dizia poder ensinar. $\mathrm{Na}$ época, a educação básica dos jovens - gramática, ginástica e música passou a ser insuficiente frente a essas novas exigências da democracia, uma vez que para um governante, mais do que decretar leis era preciso convencer a todos que essas

3 Para um estudo mais detalhado acerca do sentido do termo sofista ou sobre a história da sofística, indico a leitura de Unstersteiner (1949), Kerferd (1981), Guthrie (1991) e Cassin (1995).

4 Górgias e Antifonte foram os mais "afortunados" nesse caso, pois deles sobreviveram escritos considerados diretos. 
leis devessem ser decretadas. Além disso Atenas não possuía nenhuma espécie de instituição voltado ao ensino superior onde se ensinasse a argumentar, preparar e expor bons discursos. Era basicamente o "estudo" dos poetas que educava os jovens e tais ensinamentos já não davam conta dessa nova realidade.

Eis que surgem os sofistas, homens que dominavam a "ciência" da época, investigavam o "conhecimento", conheciam as doutrinas dos fisiólogos, debruçavam-se sobre o idioma grego e sua gramática; além de estarem dispostos a oferecer uma educação acerca desses conhecimentos que possuíam que fosse voltada para a formação da cidadania e ao ensino da eloquência. Tudo isso em troca de salários e aqui é onde surge uma das grandes oposições a esses homens: a sabedoria, a virtude ou excelência (arete), não eram tidas como coisas que se ensinavam em troca de dinheiro, antes, a relação entre discípulo e mestre deveria ser fundada na amizade e na estima, não podendo os méritos dos "mestres" serem pagos em dinheiro 5 nem o conhecimento alcançado através deste.

\subsection{Profissionalismo, currículo e métodos de ensino}

O fato de receberem honorários pelo seu ensino é uma das características distintivas do profissionalismo dos sofistas ${ }^{6}$, mas é também uma das razões de serem atacados e reprovados por alguns opositores. Muitas são as conjecturas acerca do real motivo de tal reprovação, dado que àquela altura eram muitos os bens vendidos em troca de dinheiro: poetas, médicos e artistas recebiam quantias pelos serviços específicos que ofereciam. A clássica resposta para essa questão é aquela a que acabamos de aludir, a saber, que sabedoria e virtude não eram coisas que podiam ser vendidas. Kerferd (1981, p. 25-28), contudo, atenta para outra característica das objeções de Platão e Xenofonte, a qual está no fato de que os sofistas vendiam sabedoria a todos os que se apresentassem dispostos a pagar seus honorários, ou seja, ao cobrar um preço em dinheiro eles perdiam qualquer direito de escolher seus alunos, teriam que aceitar qualquer pessoa que tivesse o suficiente para pagar-lhes, e por fim acabariam virando "escravos" de todo aquele que se lhes apresentasse com dinheiro, perdendo então sua liberdade. Entretanto, não está bastante claro o fato de que eles realmente não pudessem recusar alunos. O próprio Platão, por exemplo, expõe um jovem ansioso chamado Hipócrates que não está seguro

5 Conferir Xenofonte, Memoráveis, I 2,7-8.

6 Segundo Platão, em Hipias Maior, cobrar honorários pelo ensino é uma inovação em relação aos seus antecessores. 
sobre ser aceito por Protágoras e pede a Sócrates que o recomende (Protágoras, 310d6 e3). Desse modo, Kerferd sugere que o real motivo da objeção estaria no fato de que todo o tipo de gente poderia obter o que os sofistas tinham para oferecer, algo que não parecia ser de pouca monta: uma preparação dos homens para uma carreira na vida pública e política, através do ensino da eloquência.

Seja como for, parece que os sofistas não tiveram grande dificuldade em encontrar alunos que estivessem dispostos a pagar seus honorários, de modo que ao mesmo tempo em que eram condenados por alguns, eram aprovados por vários outros atenienses. Algo que parece refletir as tensões internas da própria sociedade ateniense, que passava por um período de transição na sua vida social e intelectual. A educação ${ }^{7}$ fora, até então, privilégio de alguns poucos que a herdavam de suas nobres famílias junto com suas riquezas. Essas famílias defendiam também que havia um caráter hereditário das boas disposições naturais. Portanto, não é de espantar que alguns mais velhos, ricos e conservadores não vissem com bons olhos a possibilidade de a educação ser aberta a quem quisesse e pudesse pagar, assim como também aos pobres poderia causar incômodo, já que não possuíam uma situação econômica que lhes possibilitasse acessar esse ensino, uma vez que os conteúdos e técnicas que os sofistas estavam aptos a oferecer era um caro produto voltado para os que buscavam fazer carreira na vida pública e política. Não estavam ali contribuindo para a educação das massas e sim preparando homens para uma carreira na política.

No que diz respeito a seus métodos de ensino, estes pareciam ser bem diversificados, indo desde conferências públicas (epideixeis), apresentadas gratuitamente a quem interessasse assistir, até cursos apresentados a um pequeno público, além de aulas particulares. Essas exibições públicas eram de modo geral uma única exposição que não se repetia da mesma maneira, aconteciam em praças e prédios públicos de Atenas ou de qualquer cidade a qual o sofista estivesse visitando. Temos testemunhos de que Górgias, por exemplo, se ofereceu para falar sobre qualquer assunto no teatro de Atenas (DK 82 A 1a), tendo proferido discursos também em Olímpia, em Delfos e nos Jogos Píticos (DK 82 B 7-9). Sabemos pelo Hípias Menor de Platão que Hípias fez apresentações regulares nos jogos em Olímpia, também se dispondo a falar sobre qualquer assunto de uma lista que ele preparava antecipadamente. Pródico parece

7 Para uma descrição mais detalhada da educação grega tradicional e as mudanças advindas com a nova democracia, indico a leitura da influente Paideia de Jaeger (1995). 
ter feito apresentação no Liceu (DK 84 B 8) e inúmeros outros testemunhos ${ }^{8}$ confirmam $^{2}$ essa prática das conferências públicas que consistia, de modo geral, em falar sobre um assunto específico e responder a quaisquer perguntas do público. Alguns desses discursos eram preparados antecipadamente e lidos ao público, e eram muitas vezes exercícios retóricos sobre algum tema mítico - como parecem confirmar os discursos sobreviventes de Górgias: Defesa de Palamedes e Elogio de Helena -, que pareciam preparar os ouvintes para falar em público, em assembleias ou tribunais.

Mais importantes que as exibições públicas parecem ter sido os cursos apresentados a uma pequena plateia. Temos notícias disso exatamente através do Protágoras de Platão, onde é descrito um encontro de sofistas na casa de Cálias. Hípias discursava para alguns ouvintes sobre astronomia, enquanto Pródico também apresentava uma aula a outros ouvintes em outro cômodo da casa. Protágoras estava lá acompanhado por um grande número de alunos atenienses e não atenienses que o seguiam por onde fosse.

Existem também indícios ${ }^{9}$ de que os sofistas se utilizavam do método de perguntas e respostas curtas, além dos discursos longos para um grande ou pequeno grupo. Saber discursar tanto longamente como brevemente seria, segundo os Discursos Duplos (DK 90 8.1), marca de um homem que conhece a verdade das coisas. Esse fato fez alguns estudiosos, como o já citado Kerferd (1981, p. 55-57), associar a figura de Sócrates à sofística, uma vez que a técnica de perguntas e respostas era a base do que conhecemos sobre método socrático. Não só os modernos parecem ter associado Sócrates aos sofistas. Na própria antiguidade, Aristófanes faz o mesmo na sua comédia Nuvens, onde tece uma forte crítica ao novo modelo sofístico de educação ao atribuir todas as características de um sofista à figura de Sócrates. Seja como for, não é do meu interesse aqui incluir ou não Sócrates nessa classe de homens chamados sofistas, apenas atento para o fato de já o terem feito graças ao método de perguntas e respostas utilizado por Sócrates, o qual parece ter sido também amplamente utilizado pelos sofistas.

Além de todos esses métodos de exposição oral, é provável que seus discípulos tivessem acesso a manuais escritos que cobriam tanto a argumentação retórica como o uso correto da linguagem, além de modelos semelhantes aos discursos epidíticos e

8 Para mais testemunhos, indico a leitura da tradução portuguesa da doxografia sofística - reunida por Diels e Kranz na famosa obra Die Fragmente der Vorsokratiker - feita por Ana Alexandre Alves de Sousa e Maria José Vaz Pinto (2005).

9 Novamente o Protágoras de Platão, mas não apenas. Temos ainda o testemunho do discurso sofístico anônimo chamado Discursos Duplos (dissoi logoi). 
apologias. A exposição e a crítica da poesia também foram inseridas em sua arte dos discursos. Atestam isso desde doxógrafos antigos até comentadores modernos ${ }^{10} \mathrm{e}$ inclusive temos exemplo de uma coleção de discursos de Antifonte, conhecidos como Tetralogias, que seriam exercícios retóricos para serem usados como modelo de argumentação em tribunais. Eram uma série de quatro discursos: um discurso de acusação; uma resposta do acusado; mais um discurso de acusação tendo em vista a resposta do acusado e por fim mais um discurso do acusado tendo em vista a resposta anterior do acusador. Além disso temos os já citados discursos de Górgias.

Quanto ao que seria o currículo sofista, não parece ter havido um padrão preciso de estudos, mas para a grande maioria dos sofistas a introdução de toda aprendizagem deveria ser o cuidado e rigor no uso da linguagem. Sabe-se também que o plano sofistico de estudos vinha na sequência do currículo de preparação básica que existia antes mesmo de a sofística aparecer. $\mathrm{Na}$ Atenas democrática, frequentar essas escolas parecia ser algo normal para os atenienses livres. Esse ensino básico era composto de três partes, cada uma com o seu professor especialista: o paidotribēs era o responsável pela educação física; o citharistēs pela música; e o grammatistēs ensinava leitura, escrita e gramática. Fazendo uma analogia superficial com nosso sistema educacional atual, pode-se dizer que o sofista oferecia uma espécie de educação "superior", especializada em determinados conteúdos de acordo com o interesse de cada um.

\section{Os homens e seus interesses particulares ${ }^{11}$}

\subsection{Górgias}

Juntamente com Protágoras, Górgias é certamente um dos mais famosos sofistas. Sua sorte textual, entretanto, foi maior que a de Protágoras. Dele sobreviveram duas paráfrases de um Tratado intitulado Sobre o não-ser ou sobre a natureza (DK 82 B 3), e dois textos considerados diretos, a Defesa de Palamedes (DK 82 B 11 a) e o Elogio de Helena (DK 82 B 11 a). Proveniente da cidade de Leontino, na Sicília, e, segundo afirma a quase a totalidade dos testemunhos (DK $82 \mathrm{~A}$ ), viveu até uma idade bem avançada. Constantemente é considerado como discípulo de Empédocles ${ }^{12}$, e teria tido

$10 \mathrm{Na}$ antiguidade Diógenes Laércio compilou uma lista de obras de Protágoras. Ao todo eram 12 os títulos, e na modernidade apontamos os autores já citados anteriormente nas notas 3 e 7.

11 É importante atentar que o resumo que segue não pretende dar conta da totalidade de sofistas que existiram. Limito-me a expor brevemente aqueles mais conhecidos que constam na já citada compilação de testemunhos e fragmentos feita por Diels e Kranz. 
um irmão médico ${ }^{13}$. Certamente viajou muito e, como embaixador de Leontino, fez uma famosa visita a Atenas em 427 a.C. a fim de persuadir os atenienses a se unirem a sua cidade natal contra Siracusa; existem ainda indícios de exibições suas em Olímpia, Delfos, Boécia, Tessália e Argos.

Segundo Platão, nos diálogos Mênon e Górgias, Górgias - diferente de Protágoras, por exemplo - nunca disse ser professor de virtude (areté), mas tão somente professor de retórica. A sua única capacidade enquanto professor era fazer os alunos serem mestres na persuasão, a qual, para ele, dominava todas as outras ciências, pois sem persuasão que convença uma assembleia de nada adianta o melhor conhecimento político, por exemplo. O discurso seria para Górgias algo "neutro", que não tem uma valoração positiva ou negativa em si, mas que adquire uma valoração no uso que dele é feito. Em seu Elogio de Helena, por exemplo, ele diz no famoso fragmento oito que "o discurso é um grande soberano que, por meio do menor e mais imperceptível corpo, concretiza os atos mais divinos, pois ele pode cessar o medo, afastar a dor, produzir a alegria e aumentar a compaixão"14. Do mesmo modo, o discurso pode causar exatamente o contrário disso, ou seja, produzir medo, dor e tristeza. Essa parece ser, aliás, uma das maiores críticas que Platão faz a Górgias no seu diálogo homônimo: para Górgias a arte do discurso, ou seja, a retórica, é moralmente neutra e ele não ensina seus alunos a serem melhores do ponto de vista moral, mas tão somente a serem melhores oradores.

\subsection{Protágoras}

Protágoras é certamente o mais famoso dos sofistas, por motivos diferentes dos de Górgias, é verdade. Seus escritos não sobreviveram, nenhum deles: a maior parte do que sabemos desse homem provém de testemunhos variados, sendo grande parcela retirados de diálogos platônicos. Para se ter ideia da vastidão de referências feitas por Platão a Protágoras, dos trinta testemunhos compilados por Diels e Kranz na sua obra (DK 80 A), treze são retirados de Platão, ou seja, praticamente a metade. Além do diálogo homônimo vemos referências explícitas no Teeteto, Crátilo, Mênon, Hípias Maior, Eutidemo, Sofista e Fedro. Aliás, a mais famosa das declarações de Protágoras - a de

12 Já Platão, no Mênon (76 c), indica que Górgias é familiarizado com a teoria dos poros de Empédocles e a defende.

13 Segundo a obra homônima (456b) de Platão, Górgias certa vez ajudou seu irmão a convencer pacientes que não queriam se submeter a um tratamento médico.

14 Tradução minha.

Filosofia e Educação [RFE] - Volume 9, Número 1 - Campinas, SP

Fevereiro-Maio de 2017 - ISSN 1984-9605 - p. 110-130 
que o homem é a medida de todas as coisas - é retirada exatamente do Teeteto (151e 152 a) de Platão.

Protágoras nasceu em Abdera e vários testemunhos (DK 80 A) confirmam a informação de que morreu afogado em um naufrágio quando tentava deixar Atenas depois de ter sido julgado e condenado por impiedade, por negar os deuses da cidade. Era muito famoso em Atenas e parece ter sido amigo pessoal de Péricles, o qual o convidou para elaborar a constituição de uma nova colônia em Turói.

Segundo Platão, no diálogo homônimo, Protágoras professa ser um sofista, mestre na arte política (techne politike), e que ensinava aos seus discípulos a excelência ou virtude (arete) nos assuntos públicos e privados. Ou seja, Protágoras seria, como já dito anteriormente, capaz de educar jovens para o exercício da cidadania, para fazer obra política.

\subsection{Pródico}

Pródico nasceu na cidade de Ceos e provavelmente ainda vivia quando Sócrates morreu. Era então de uma geração um pouco mais jovem que a de Protágoras e Górgias, que devem ter vivido sua maturidade já na época de Platão. Assim como os outros sofistas, ensinou em diversas cidades, seja na forma de exibições públicas ou de aulas individuais. Dele temos ainda menos testemunhos que de Górgias e Protágoras. O mais extenso deles provém das Memoráveis (II, 1. 21-34) de Xenofonte. Trata-se de um texto que aborda um tema moral, a saber, a escolha de Héracles entre a virtude (arete) e o vício (kakia). Pródico foi famoso principalmente pela sua obra sobre a linguagem: parece ter se empenhado na análise semântica de expressões semelhantes, distinguindo os sinônimos. No Protágoras, novamente, Platão sugere que ele se interessava insistentemente pelas distinções exatas entre as palavras consideradas sinônimas. O Suda (DK A 1) o descreve como um filósofo natural e sofista, e Galeno (DK, 24 A 2) o coloca na mesma classe de "filósofos da natureza", junto com Melisso, Parmênides, Empédocles e outros. Nas Nuvens (360), Aristófanes o descreve como um perito em astronomia.

\subsection{Hípias}

Hípias nasceu em Élis e certamente era contemporâneo de Pródico, portanto era de uma geração mais jovem de sofistas. Viajou constantemente e, assim como Górgias, 
desempenhou também o papel de embaixador de sua cidade natal. A maior parte do que sabemos a seu respeito provém também de Platão, de seus dois diálogos homônimos e do Protágoras. O traço mais conhecido de sua personalidade é sua polymathia (DK 86 A), uma espécie de enciclopedismo: interessava-se desde temas antropológicos, de caráter ético-político e linguístico, até assuntos relacionados às ciências da natureza e às matemáticas. Além disso, temos o testemunho do Hípias Menor de que ele reivindicava um domínio também sobre as artes manuais, como, por exemplo, a fabricação de calçados e adornos, além de vestimentas, aliando esses conhecimentos práticos a outras competências das mais variadas, como a música, a métrica, a gramática, a pintura, escultura. Dizia-se também capaz de compor qualquer tipo de discurso e possuía uma técnica de memorização que o habilitava a lembrar mais de cinquenta nomes depois de ouvi-los uma vez só, técnica que ele provavelmente partilhava com seus alunos em suas aulas. Ainda segundo testemunhos variados (DB 86 B), produziu também uma lista dos vencedores olímpicos e uma lista de nomes dos povos. Foi-lhe atribuída também a descoberta da curva chamada quadratriz.

Diz-se que no seu currículo de ensino constavam gramática, música, ritmo, astronomia, geometria, aritmética, genealogia, história, história da filosofia, mitologia e matemática, além das já citadas artes manuais. Tudo isso nos faz deduzir que seu ideal de educação, diferente daquele dos sofistas já citados, visava a uma espécie de autossuficiência e não apenas à especialização em um determinado assunto.

\subsection{Antifonte}

Antifonte, distinto dos outros sofistas já mencionados, nasceu em Atenas e viveu provavelmente na mesma época em que Protágoras e Górgias. Juntamente com Górgias, é dos sofistas que mais sorte tiveram em relação a seus escritos ${ }^{15}$. Alguns desses escritos, porém, foram descobertos apenas recentemente, nos papiros de Oxyrinchus (em 1915 e em 1922), algo que contribui ainda mais na produção de uma identidade fragmentada pela tradição. Mas não apenas esse fato material fez com que os comentadores fragmentassem a identidade de Antifonte: desde a antiguidade há teorias de que existiriam mais de um Antifonte devido a diferentes fatores, sendo as possíveis divergências encontradas tanto nas biografias como nos estilos, léxicos e interesses de

15 Indico a leitura da compilação e tradução de testemunhos, fragmentos e discursos produzida por Bellintani (2008), a mais completa e atualizada que possuímos em língua portuguesa. 
que temos notícia. Aqui não ambiciono expor e entrar a fundo nessa disputa, mas concordo com a tese defendida de que na realidade todas essas possíveis identidades de Antifonte são apenas interesses distintos de um único Antifonte, ${ }^{16}$ algo que atesta exatamente os interesses múltiplos e variados que um sofista poderia ter, além de uma tendência mais crítica que doutrinária em relação ao conteúdo de seus ensinamentos. Fato também curioso de se atentar é que, de modo diverso da maior parte dos sofistas, não possuímos testemunhos de Platão sobre Antifonte. Seu nome não é citado diretamente uma única vez em toda a obra platônica. Seus extensos fragmentos e discursos são retirados em sua maioria do já citado papiro, além de testemunhos encontrados em alguns outros doxógrafos (DK 87 A).

Os textos e testemunhos remanescentes atestam, com efeito, interesses amplos e muito variados por parte de Antifonte que vão desde a preocupação com a linguagem (seguindo a linha da problemática da correção dos nomes) às investigações do domínio da física e da matemática, até um estudo sobre os sonhos. Mas, o que salta aos olhos em sua obra é realmente a primazia do interesse pelo político e seu envolvimento na discussão acerca da antítese entre lei (nomos) e natureza (physis) na moral e na política. Preocupou-se em examinar temas ético-políticos como, por exemplo, a natureza da Justiça, que seria "não transgredir as prescrições das leis da cidade da qual se é cidadão" (Fragmento 44a na edição de Bellintani), isto é, o cidadão membro de uma comunidade política deveria respeitar as leis sem restrições. Entretanto, é dito mais à frente no mesmo fragmento que a utilização das leis vigentes por parte do homem varia de acordo com a situação em que ele se encontra: se em uma situação pública, na presença de testemunhas ou se numa situação privada, na ausência de outros. E isso porque existe uma clara oposição entre as leis da natureza, as quais devem ser respeitadas e preferidas no privado, e as leis vigentes de uma cidade, as quais devem ser respeitadas apenas na presença de outros para o bom funcionamento da sociedade. Em outros termos, Antifonte aponta para a supremacia da natureza em relação às leis humanas, a qual deve sempre que possível ser preferida. O homem se utiliza de leis convencionadas exatamente para que possa evitar o máximo de dor e se aproximar ao máximo do prazer (que são os ditames da natureza), ou seja, o homem cria leis para tentar estar ao máximo de acordo com a natureza.

16 A respeito do problema da multiplicidade de Antifonte, e a favor de sua unidade, sugiro a leitura dos artigos de Bellintani (2008) e de Cassin (trad. bras. de 1990), os quais trazem hipóteses que partilho imensamente e abstenho-me de resumi-las aqui devido à economia de nosso texto. 
Possuímos dele ainda as famosas Tetralogias, já citadas anteriormente, que seriam discursos modelo de argumentação em tribunais para serem usados por seus alunos. Os temas das Tetralogias e dos outros discursos de Antifonte são os mais variados.

\subsection{Outros sofistas e dois escritores anônimos}

Por fim, convém citar rapidamente algumas outras personagens que figuram "marginalmente" na lista de sofistas: dos diálogos platônicos temos notícia de Trasímaco no Livro I da República, que defende um realismo político através da célebre declaração de que a justiça é a conveniência do mais forte (338 c); do recalcitrante Cálicles, no diálogo Górgias, que defendia uma completa ausência de moralidade; e de Eutidemo e Dionisodoro, dois irmãos que são ridicularizados pelas suas disputas verbais esvaziadas de sentido no Eutidemo. Há ainda testemunhos compilados em Diels e Kranz referentes a Xeníades (DK 81), Licofronte (DK 83) e Crítias (DK 88). Esse último estaria ligado a Platão por laços de parentesco, foi opositor do regime democrático de Atenas e um dos trinta tiranos.

Além desses nomes citados, temos também dois escritos Anônimos, intitulados como Discursos Duplos (DK 90) e Anônimo de Jâmblico (DK 89). O primeiro deles foi encontrado entre os manuscritos de Sexto Empírico sem qualquer menção ao nome do autor ou título, escrito em um tipo de dialeto dórico com elementos jônicos, e seu título moderno provém das palavras iniciais de seu primeiro capítulo. Sua estrutura consiste, em linhas gerais, em opor argumentos a respeito de termos morais ou filosóficos considerados opostos, como, por exemplo, verdadeiro e falso, bom e mau, belo e feio. Devido ao fato de trazer um método parecido com o de Protágoras - que diziam sustentar que existiam dois argumentos contrários para cada assunto - algumas vezes sua autoria foi atribuída ao sofista. Entretanto, os comentadores modernos descartaram essa hipótese e são unânimes em afirmar a impossibilidade de se definir sua autoria.

Já o Anônimo de Jâmblico foi descoberto em 1889, por Friedrich Blass, no Protréptico, de Jâmblico, um neoplatônico do século III d.C. Tal obra reunia materiais diversos, de diferentes filósofos - incluindo uma porção considerável do Protréptico, de Aristóteles. Blass demonstrou então que cerca de dez páginas, estas hoje intituladas como Anônimo de Jâmblico, provinham de uma fonte não identificada. A problemática do texto gira em torno da famosa oposição entre natureza (physis) e lei (nomos), entre o 
que existe por natureza e o que existe por convenção - tema caro à quase totalidade dos sofistas - e o autor defende que as leis são convencionadas e não naturais. Por conta disso, atribui-se o texto a um autor sofista, sendo impossível, entretanto, a definição de sua autoria.

\section{Objetos de interesse e ensino de alguns sofistas}

Chego, então, ao último momento deste trabalho, onde exporei alguns temas caros aos mais famosos sofistas e uma caracterização mais detalhada - efetuada em grande parte por Platão - deles enquanto professores profissionais. Jaeger (1995, p. 340-341) afirma que o ensino que os sofistas pareciam ofertar era a virtude (arete) do homem político, de um cidadão da polis, que era vista sobretudo como capacidade oratória e intelectual. Antes de entrar na clássica problemática sofística e platônica a respeito de saber se a arete é algo que possa ser ensinado, convém atentar a uma outra famosa controvérsia sofística entre o que seja a natureza (physis) e a convenção ou lei (nomos) na moral e na política, pois só a partir das respostas esboçadas aqui - ou problemas colocados - seria possível entender qual o caráter da arete para um sofista e, consequentemente, se ela é matéria que pudesse ser ensinada.

\subsection{A controvérsia sofística ente nomos e physis na política e na moral ${ }^{17}$}

Os dois termos são palavras-chave do pensamento grego nos séculos V e IV a.C., os quais inicialmente não são palavras que aparecem em oposição nos primeiros escritores, mas, a partir do V século a.C. são consideradas contrárias e excludentes: algo que existe por physis não pode existir por nomos e vice-versa. Physis é um termo comumente traduzido por "natureza", muito usado pelos chamados filósofos pré-socráticos para nomear a totalidade da realidade ou seus componentes mais permanentes. $\mathrm{O}$ termo parece também se referir àquilo que é dado simplesmente, que está na origem de tudo e independe do homem ou de qualquer ser vivo. É algo que está numa esfera mais global de todo tipo de ser: todo ser vivo possui uma physis, ou seja, possui uma "natureza própria”, características particulares e intrínsecas a ele próprio.

17 Limito-me aqui a acenar brevemente sobre o sentido corrente dos termos nomos e physis à altura em que aqueles sofistas descritos mais acima estavam ativos e em suas posições mais claras. Para um estudo mais detalhado acerca dessa famosa controvérsia indico a leitura dos capítulos dedicados por Kerferd (1981) e Guthrie (1991) a esse tema, sobre os quais baseio a presente exposição. 
Nomos é um termo comumente traduzido por "lei", "convenção" ou "costume", a depender do contexto que se apresente. Significa basicamente algo convencionado ou estabelecido por homens, algo que pressupõe agentes que estabelecem e praticam esses mesmos nomoi. É um termo que, de modo geral, prescreve e não descreve, e por isso, Kerferd (1981, p. 12) sugere como melhor tradução moderna o termo "norma". Os nomoi são prescrições convencionados a respeito do que se deve ou não fazer. Sendo assim, diferentes povos possuem diferentes nomoi ao passo que a physis seria algo mais universalmente partilhado entre diferentes espécies.

A oposição entre esses dois termos dentro do campo da moral e da política dizia respeito então a saber se existiriam valores e atos "naturalmente" válidos, ou seja, válidos por physis, ou se seriam apenas "convencionais"; dito de outro modo, válidos apenas por nomoi. Em termos mais simples podemos dizer que a questão mais cara era saber se existiam valores universalmente válidos, característicos de toda a espécie humana, ou se esses valores se modificavam de acordo com os diferentes tipos de sociedade humana. A partir da resposta a esta questão é que o homem poderia considerar o seu modo de agir e de seus concidadãos como "correto" ou não. Também só a partir dessa resposta poderiam professar o ensino da arete: se ela fosse algo dado por physis, não seria possível que fosse ensinada; se fosse algo dado por nomos não só seria possível como seria preciso que fosse ensinada.

As respostas sofísticas foram múltiplas e não parecem categóricas; algumas delas inclusive são altamente contrastantes, o que corrobora o cuidado que devemos ter ao atribuir características "gerais" a todos aqueles que são chamados sofistas. Há os que defendiam a physis e outros o nomos, e há ainda aqueles que defendiam uma espécie de "realismo amoral" que se limitava a descrever a sociedade como se lhes parecia e estavam preocupados antes de tudo com uma espécie de "utilitarismo": o "justo" seria o que é mais útil ao homem dentro de uma sociedade e também em seus assuntos privados. Não existiria, portanto, o "justo" em si, fosse entendido como natural ou convencional. E se esse "justo" em si existisse não poderia ser conhecido pelo ser humano. O justo era considerado de acordo com as necessidades naturais $\mathrm{e}$ convencionadas pelo homem em sociedade, a depender do momento.

Como exemplo de defensores do nomos temos o Protágoras do diálogo homônimo de Platão, que rejeitava - no famoso mito de criação dos humanos - que a virtude política, ou seja, a justiça, fosse inata nos homens desde o começo, apesar de 
todos a possuírem em graus diversos no mundo atual. Ou seja, para o Protágoras platônico, na natureza humana, em sua physis, há já a possibilidade de um avanço moral, mas este avanço é conseguido apenas graças à educação e aos nomoi estabelecidos em uma sociedade. Para o Protágoras de Platão, o senso de justiça é uma virtude necessária para a sobrevivência dos seres humanos em sociedade, não sendo algo "natural", mas potencialmente humano e construído através dos nomoi - fixados pelo Estado - que ensinam aos cidadãos quais são os limites de suas ações dentro de uma sociedade.

Como defensor da physis temos o já citado Antifonte. As consequências de sua preferência pela physis face ao nomos levam, entretanto, a posições bem contrastantes: por um lado essa preferência pode levar a um perigoso egoísmo - que faz lembrar uma alcova de $\mathrm{Sade}^{18}$ - ao dizer que o ser humano pode ignorar o nomos caso não esteja sendo observado por outro(s), mas também ajuda a eliminar aquilo que hoje conhecemos como xenofobia ao dizer que segundo a physis todos os humanos são iguais e que a única coisa que distingue gregos e bárbaros são os nomoi. Antifonte, entretanto, nunca nomeou categoricamente o que seria isso que ele chama de physis, limitando-se apenas a caracterizá-la em oposição ao nomos. Ao defender tal posição contrastante fica talvez óbvio o fato de Antifonte não ter sido muitas vezes referido como professor de arete, uma vez que seus ensinamentos parecem trazer uma espécie de moralidade ambígua.

Por fim, incluo o sofista Górgias entre aqueles que eu chamei mais acima de "realistas amorais". Sua teoria do conhecimento, exposta no Tratado Sobre o não-ser parece confirmar isso. É aí que Górgias expõe suas famosas três teses: 1) Nada é; 2) Se é, é incognoscível; 3) Se é e [se é] cognoscível, não pode ser mostrado a outros. No meu entendimento, tais teses significam dizer que, ainda que exista uma natureza nas coisas, características próprias dos seres vivos, o ser humano não consegue acessar essa natureza e, portanto, deve estabelecer por meio de palavras - previamente definidas pelos falantes - aquilo que julga ser a "verdade" e a "justiça" das coisas. As consequências disso, parece-me, são uma "suspensão" do juízo acerca da natureza das coisas - mas não uma negação absoluta de que as coisas possam possuir uma natureza própria - e uma ênfase maior nos próprios atos do homem em sociedade e também na sua prática discursiva. Talvez, por isso, Platão expõe no seu diálogo homônimo um 18 No já citado artigo de Barbara Cassin (nota 17), é feita uma aproximação possível entre as ideias morais de Antifonte e as do - famoso por sua imoralidade - Marquês de Sade. 
Górgias que está absolutamente certo de não ensinar arete para qualquer um de seus alunos, mas tão somente a arte da retórica, a arte de bem falar e persuadir, a qual é moralmente neutra e pode ser usada tanto com justiça quanto com injustiça, a depender de quem usa e em que contexto usa. Se Górgias proferisse que pode ensinar arete, ele teria de previamente definir o que ele considera ser isto, e isso não parece ser feito em qualquer um de seus escritos, muito ao contrário: de todos os escritos sobreviventes de Górgias não conseguimos encontrar, uma única vez, uma definição dogmática sobre o que seria a verdade das coisas, senão uma alusão de que a verdade das coisas - no âmbito puramente humano - é algo estabelecido. Por isso não considero que Górgias seja um partidário da physis ou do nomos, pois o "fato" é que pode ser que as coisas tenham uma natureza, mas o que regula a vida do homem em sociedade são os nomoi.

Diferente de Protágoras e de Antifonte, Górgias não afirma categoricamente que a justiça seja algo natural ou convencionado pelo homem, mas que tudo que podemos conhecer acerca dela são suas aparições humanas dentro de uma sociedade. Ou seja, pode ser que exista uma justiça natural, mas o que verdadeiramente é acessado pelo homem são apenas suas aparições na sociedade e em forma de nomoi. De modo que sua posição me parece ser amoral em um sentido bem preciso e que é corroborado pelo testemunho de Platão no Mênon: se existe uma arete "em si mesma", uma excelência universal de todas as coisas, ela não é conhecida e é preciso observá-la em diferentes tipos de seres vivos; assim, existe a arete de um homem, de um cavalo, de uma cidade, de um corpo, de um discurso etc., parecendo ser a arete dos discursos o conteúdo de seus ensinamentos.

\subsection{Então, a arete pode ou não ser ensinada?}

Chego, então, ao momento final do trabalho, onde exporei em detalhes o diálogo Protágoras, de Platão - o único que pode ser considerado uma clara caracterização do sofista como professor de "excelência" humana. Aquilo que caracterizaria o modelo mesmo de uma educação mais "humanística" e "abrangente" do século V, em oposição à tradicional educação aristocrática que era transmitida de pai para filho e tinha direta relação com a nobreza e a estirpe familiar dos pequenos grupos de indivíduos que comandavam as cidades.

É importante, antes de tudo, definir os significados de arete nessa nova sociedade democrática: de modo geral esse termo denotava todas as qualidades de um 
homem que contribuíam para sua vida em sociedade e que lhe garantiriam uma posição de destaque nessa mesma sociedade. Portanto, a possibilidade mesma de a arete poder ser ensinada influenciaria profundamente a estrutura da cidade na qual esse ensino fosse levado a cabo, já que a aquisição dessa aprendizagem tornava qualquer um - que tivesse condições econômicas de pagar por ela - apto a atingir um estatuto político bastante privilegiado. Segundo Kerferd (1981, p. 131), o ensino da arete seria, portanto, uma chave para a mobilidade social.

Não deve ter sido à toa, então, que o debate acerca de a arete poder ou não ser ensinada foi objeto de investigação de vários autores dos séculos V e IV a.C, desde os sofistas até Platão, pois era questão de grande importância para o homem democrático. Tampouco seria possível a qualquer sofista afirmar categoricamente que arete não pudesse ser ensinada, assim como hoje em dia seria estranho que um professor proferisse a opinião de que é impossível haver educação. Havia, claro, os sofistas que se colocavam fora dessa questão ou que simplesmente suspendiam seu juízo, mas a declaração de que não pudesse ser ensinada realmente nunca foi atribuída por nenhum dos testemunhos sobre os sofistas. Nem mesmo de Górgias ou Antifonte se diz que não pudessem ensinar arete; os dois apenas pareciam se abster do debate, afirmando que sua atividade professoral se assentava em outros objetos.

Algumas das tradicionais objeções levantadas quando se tentava demonstrar que a arete pode ser ensinada - elencadas nos Discursos Duplos - eram as de que é impossível reter com você alguma coisa que você entregou a outra pessoa; que teria havido professores de arete reconhecidos se ela pudesse ser ensinada; que os homens sábios teriam transmitido sua sabedoria a seus familiares e amigos; que alguns alunos tinham ido aos sofistas e não tinham obtido nenhum benefício; e que muitas pessoas que se elevaram em uma sociedade não estiveram associadas a eles.

Interessa-me considerar esses argumentos na discussão do diálogo Protágoras, de Platão. No início do livro, encontramos Hipócrates (um jovem ansioso) antes de o dia amanhecer, despertando Sócrates e lhe pedindo para que o levasse até o sofista a fim de tornar-se sábio. Quando Sócrates os apresenta, Protágoras declara que se propõe a ensinar-lhe a prudência nos negócios domésticos que o capacite a dirigir sua própria casa, e a sabedoria nos negócios públicos que melhor o qualifique para falar e agir nos negócios do Estado (318e). Sócrates então pergunta se essa é a arte da política (techne politike), e se Protágoras se encarrega de fazer dos homens bons cidadãos. À afirmativa 
de Protágoras, Sócrates replica dizendo supor que essa arte não pudesse ser ensinada por dois motivos: primeiro, os atenienses inserem nas assembléias especialistas para aconselhá-los em assuntos técnicos, mas, no que diz respeito a assuntos relativos à cidade, julgam todos os cidadãos capazes de dar conselhos (319 b-d); e, segundo, os melhores e mais sábios cidadãos não são capazes de transmitir essa arete a outras pessoas (319d-320b).

Protágoras então responde em forma de mito, seguido de um "argumento" (logos). O mito é bastante conhecido e se estende de $320 \mathrm{~d}$ até $322 \mathrm{~d} 6$ e descreve como Epimeteu, antes do dia predeterminado pelos deuses para os seres mortais saírem da terra e irem à luz, distribuiu as várias faculdades e capacidades entre os animais seguindo um princípio igualador, para dessa forma evitar a possível extinção de qualquer uma das raças. Porém, de maneira descuidada, acabou seu estoque de faculdades e capacidades com os animais irracionais e dessa forma os seres humanos ficaram desprotegidos, completamente não equipados. Foi quando Prometeu, desesperado, sem saber que forma de preservação poderia conceder aos humanos, roubou de Atena e Hefaisto a sabedoria nas artes práticas juntamente com o fogo, capacitando-os assim para viver. Ao chegar à superfície terrestre os homens desenvolveram a fala, a religião e os elementos materiais da civilização. Tentaram assim viver unidos e fundar cidades para garantir a sobrevivência. Entretanto, faltava-lhes a arte política e, mal começaram a viver juntos, começaram a praticar injustiças entre si. Foi então que Zeus, temendo o fim da espécie, enviou Hermes para dar aos homens aidos (uma espécie de pudor frente ao olhar do outro) e dike (justiça) para thes garantir a proteção. As artes (technai) foram distribuídas entre os homens da mesma forma como as capacidades entre os animais, porém, aidos e dike deveriam ser dadas a todos os homens igualmente, pois só assim seria possível formarem cidades e se preservarem.

Dessa forma, Protágoras mostra que todos os homens participam de alguma parte da justiça e da virtude cívica e imediatamente declara que essa participação não é "por natureza", nem adquirida espontaneamente, mas sim através da instrução e da prática. Caso não fosse assim, não existiria motivo de haver a punição. Nas sociedades civilizadas a punição é uma forma de ensino; não se punem outros por defeitos naturais ou casuais, mas sim por falta de aprendizado, por deficiência em justiça e arete e com vista a que o cidadão "aprenda" (324a 4 - c7). Assim, fica demonstrado, por ambos os motivos, que justiça e arete são consideradas ensináveis. 
A essa altura, Protágoras já abandona o mito e continua com seu logos para responder três pontos que ficaram pendentes: se não é por natureza, como todos os homens obtêm sua participação na justiça? Por que os homens considerados bons não ensinam virtude aos filhos? E por que os filhos de homens tão notáveis algumas vezes deixam de manifestar a excelência dos pais? A resposta dada é que, como a arete é a base de todas as atividades, na infância ela é ensinada de todas as formas correntes, ou seja, por pais, amas, professores. Quando crescidos, ela é ensinada pela comunidade através das leis e punições.

O que Protágoras parece dizer é que esse ensino da arete é universal através da comunidade e que os que a ensinam não têm um nome em especial. E quanto à diferença na arete entre pais e filhos, isso não pressupõe que os homens bons não eduquem seus filhos na arete; eles realmente se esforçam nisso, mas acontece que existem variações de aptidões naturais. E isso se verifica sempre que algumas pessoas têm praticamente o mesmo ensino e as mesmas oportunidades de aprender e se comportam de modos distintos em relação a um mesmo assunto. Além disso, algumas pessoas adquirem mais instruções do que outras e alguns professores são melhores do que outros. E é um desses professores que Protágoras julga ser. Para ele é possível ensinar a alguém como ser um homem bom, ensino que inclui condicionamento nos costumes sociais e instrução em técnicas específicas como, por exemplo, a retórica; e que as disposições de caráter não são idênticas entre si.

\section{Considerações finais}

Tentamos deixar claro que ao falar sobre o que é um sofista e o que seria a educação sofística não é possível prescindir de uma constante referência ao que Platão e outros autores disseram sobre eles, pois de seus próprios textos nenhuma referência direta é feita aos seus ensinamentos. Além disso, tentamos mostrar que seus objetos de interesse particular e de ensino não podem ser considerados todos iguais, temos posições inclusive contrastantes entre esses homens, de modo que ao evocar o termo "sofista" devemos ter sempre o cuidado em enunciar sobre quem se está falando e a partir de qual testemunho.

Apesar disso, parece ser difícil negar que esses homens foram peças fundamentais na formulação de um novo tipo de educação humana e que tinham algo em comum que permitiu unir todos eles por um único nome: seu interesse crítico pelo 
ser humano e por todas as coisas que diziam respeito a sua vida em uma sociedade. Os testemunhos são algumas vezes divergentes e outras tantas carregam certa hostilidade em relação ao ensino levado a cabo por esses homens. Apesar disso, é possível afirmar que eles tentaram debater e ensinar tudo aquilo que dizia respeito ao ser humano de seu tempo - e que atualmente poderíamos chamar de "ciências humanas" -, como teorias morais e filosóficas, teorias linguísticas e gramática, teorias sobre os deuses e a natureza e origem humanas, críticas e análises literárias, além de física, ciências "naturais" e matemática.

\section{Referências bibliográficas}

\section{Edições e traduções dos textos antigos}

BELLINTANI, Luiz Felipe. Antifonte: Testemunhos, Fragmentos e Discursos. São Paulo: Loyola, 2008.

DIELS, Hermann; KRANZ, Walther. Die Fragmente der Vorsokratiker, v. 2. Berlin: Weidmann, 1922.

PLATÃO. Platonis Opera. Ed. John Burnet. Oxford: Clarendon, 1968. . Górgias. Trad. Daniel R. N. Lopes. São Paulo: Perspectiva: FAPESP, 2011.

. Sofista. Trad. port. Henrique Murachco, Juvino Maia Jr. e José Trindade Santos. Lisboa: Calouste Gulbenkian, 2011.

Protágoras. Trad. port. Ana da Piedade Elias Pinheiro Lisboa. Lisboa: Relógio D’Água, 1999.

. Eutidemo. Trad. Maura Iglésias. Rio de Janeiro: Ed. PUC-Rio; São Paulo: Loyola, 2013.

Teeteto. In: Diálogos de Platão. Trad. Carlos Alberto Nunes. Belém: Universidade Federal do Pará, 2001.

UNTERSTEINER, Mario. Sofisti, Testimonianze e Frammenti. fascs. 2. Firenze: La Nuova Italia, 1949.

SOFISTAS. Testemunhos e Fragmentos. Trad. port. Ana Maria Alexandre Alves de Sousa e Maria José Vaz Pinto. Lisboa: Imprensa Nacional-Casa da Moeda, 2005. 


\section{Comentadores}

BELLINTANI, Luiz Felipe. Um Antifonte Múltiplo. Anais de Filosofia Clássica, v. 2 n. 4, 2008.

CASSIN, Barbara. L'effect sophistique. Paris: Gallimard, 1995. "A Verdade de Ântifon: uma democracia sádica" In: Ensaios sofísticos. Trad. Ana Lúcia de Oliveira e Lúcia Cláudia Leão. São Paulo: Siciliano, 1990.

CAVALCANTE, Gabrielle. Sobre Górgias: Nem ser nem não-ser. 2016. Dissertação de Mestrado em Filosofia. UnB, Brasília.

GUTHRIE, W.K.C. The Sophists. 8.ed. Cambridge: Cambridge University Press, 1991.

KERFERD, G.B. The Sophistic Movement. Cambridge: Cambridge University Press, 1981.

WERNER, Jaeger. Paidéia: a formação do homem grego. 3.ed. Trad. Artur M. Parreira. São Paulo: Martins Fontes, 1995. 